\title{
Broke and broken in America? No way, experts say
}

$\mathrm{T}$ he refrain has become as common as the apparent use of steroids in baseball: Medicare is broke and broken.

The complaints have become legion: the national social insurance program administered by the United States government to provide access to medical services for Americans aged 65 or older, and younger people with disabilities, will run out of money in 2024. The traditional fee-for-service payment system for physicians and hospitals is untenable and some manner of competitive bidding must be introduced to reduce the cost of services.

The proposed solutions, meanwhile, have been diverse. Hike the retirement age or limit Medicare eligibility to age 70. Raise taxes to stave off insolvency. Impose a means test to cut out the rich. Cut costs. Cut benefits. Introduce some manner of premium-based Medicare that would involve giving money to senior citizens in the form of vouchers, which they could use to purchase health insurance, rather than having the federal government absorb the cost of their health care (www.cmaj.ca/lookup /doi/10.1503/cmaj.109-4237).

In short, the state and fate of Medicare - which provided coverage to roughly 40 million seniors and about 8 million younger people with disabilities in 2010 , at a cost of roughly $\$ \mathrm{US560}$ billion are rapidly becoming the battleground on which the American election will be fought this fall.

But several experts contend the problems facing Medicare are exaggerated and do not necessitate the radical reform that some claim are needed because of the aging population and rising health care costs.

That the Medicare program has been subject to accusations and "politicallyinflammatory statements" is to be expected given the looming federal election, says Gerald Kominski, director of the Department of Health Policy and Management in the Jonathan and Karin Fielding School of Public Health at the

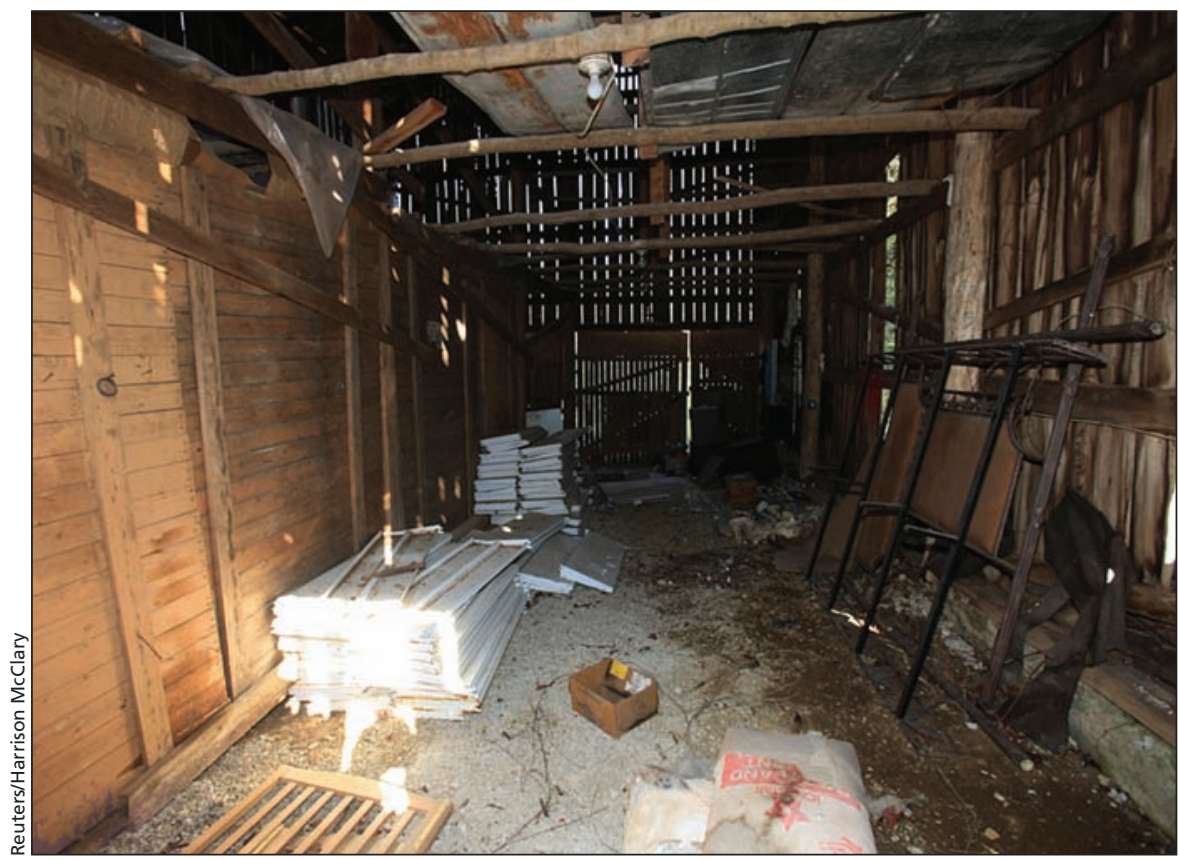

The interior of an abandoned tobacco barn that was listed as the location of "Gainesboro Ultimate," a clinic that billed the United States Medicare program for more than US\$200 000 to treat patients suffering from severe combined immunodeficiency disease, also known as "bubble boy disease," in Gainesboro, Tennessee.

University of California, Los Angeles. Seniors represent a massive voting bloc both parties are eager to secure, making Medicare "a hot-button issue."

It is in the nature of political discourse that facts are distorted and threats are manufactured in an effort to mobilize voters, Kominski adds. But is the Medicare program actually "broke? No. But the Republicans are campaigning on a platform that says Medicare needs to be fundamentally restructured and cut to limit government liability to the program."

In truth, the program is "on a firmer footing than it's been in awhile," Kominski contends. Passage of the Patient Protection and Affordable Care Act in 2010 increased the pool of funds available to Medicare by imposing a $0.9 \%$ payroll tax on individuals with earnings of more than US\$200 000 and couples or families with combined salaries upwards of US $\$ 250000$, a move that is projected to generate an additional US $\$ 300$ billion for the program over 10 years, he says.
The very notion that the Medicare program could achieve bankruptcy is a non sequitur as the program's structure is such that its various components are funded differently, argues Richard Kaplan, professor of law at the University of Illinois at Urbana-Champaign. Only one component - Part A, which covers charges originating from hospitals, nursing homes, home health services and respite care - is supported through revenues from a trust fund, which could theoretically run out. But both Part B, which covers charges by physicians, paramedic services and the cost of equipment such as walkers, and Part D, which covers prescription drugs, are funded through tax revenues and premiums paid by enrollees in the program. That effectively makes them immune from bankruptcy unless people stop using the program and governments stop financing it, he says.

And should Part A trust-fund coffers run dry, nothing precludes the government from funnelling more money 
into the chest to keep the program afloat, he adds. "It's not like there's some kind of unusual element to go ahead and just pay for it out of current revenues just as we do with the justice department, the Supreme Court, environmental protection, the defence budget - none of those things have trust funds. None of them have any kind of preset money set aside."

It's a question of priorities, Kaplan says. "One could say: 'Why don't we bring the defence budget in line with the average of the OECD [Organisation for Economic Co-operation and Development] countries?' That would free up a fair bit of money that could be spent on tax cuts, on education or it could be spent on funding Medicare."
Kaplan dismisses the argument that the rising costs of care make the program unsustainable. "That doesn't mean it's broke; it just means, whoa, we need to control this or else it's going to take up an increasing percentage of our budget."

Similarly, the so-called "demographic bulge" of baby boomers is a "predictable and manageable challenge," Kominski says. "There are responsible steps for managing that and there are, in my opinion, irresponsible steps. Dismantling the program as we know it I think is an extreme reaction, but understandable because it's one way of saying 'the sky is falling, therefore we have to fundamentally change the program'."
That's not to say that reforms aren't needed, Kaplan says, citing the need to examine features of the program that contribute to its high cost, such as its openended nature, which affords beneficiaries the luxury of receiving care from "any willing provider," no matter the price, which makes it impossible to predict the year-to-year cost of Medicare, he adds. "We can perhaps guess how many people are going to get sick and from certain illness based on historical patterns, but these are all individual decisions as to how much care they're going to get and where they're going to get it. It's part of the appeal of Medicare, but it's also a cost driver." - Michael Monette, CMAJ

CMAJ 2012. DOI:10.1503/cmaj.109-4297 